\title{
Comparative study between sharp dissection and electro cautery dissection in incisional hernia surgery
}

\author{
Omar Saad Mahmood ${ }^{\star}$, Khalaf Rasheed Jadoa** \\ *Postgraduate Student , Department of Surgery, College of Medicine , University of Mosul \\ ** Department of Surgery, College of Medicine , University of Mosul , Mosul , Iraq \\ Correspondence: omarsaadirq@gmail.com
}

(Ann Coll Med Mosul 2020; 42 (2):169-176).

Received: $16^{\text {th }}$ Sept. 2020; Accepted: $11^{\text {th }}$ Nove. 2020.

\begin{abstract}
Background: Incisional hernia is a common problem in our surgical practice and it poses a challenge due to its high incidence of complications like seroma and surgical site infection (SSI) .

The objective of this study: is to assess the contribution of diathermy to postoperative seroma formation and wound complications in incisional hernia surgery and also to assess other predictors for wound complications including comorbidities, personal and hernia characteristics.

Patients and Methods: This is a prospective case series study comparing two types of flap dissection in cases of open incisional hernia mesh repair. Sixty patients randomized in to two groups of abdominal flap dissection, one group with electro cautery dissection and other group with sharp dissection by scissors and knife. Surgical procedure was the same between the two groups. Primary outcome measures were postoperative seroma, SSI and wound dehiscence.

Results: There was no significant difference in seroma formation $(p=0.738)$, SSI rate $(p=0.641)$ and wound dehiscence rate $(p=0.150)$ between the electro cautery group and the sharp dissection group. The use of cautery leads to reduction in the intraoperative blood loss $(p<0.0001)$ and operative time $(p<0.0001)$. The relation between body mass index (BMI), diabetes mellitus (DM), hernia length, width and postoperative seroma was highly significant $(p=0.002,0.034,0.002,<0.0001$ respectively).

Conclusions: The use of cautery instead of scissors during flap dissection does not result in increased postoperative wound complications in incisional hernia patients. The use of cautery lead to reduction in the operative time and intraoperative blood loss. The relation between DM, BMI, hernia defect size and increased rate of wound complications was significant.
\end{abstract}

Keywords: cautery , scissors, seroma , surgical site infection.

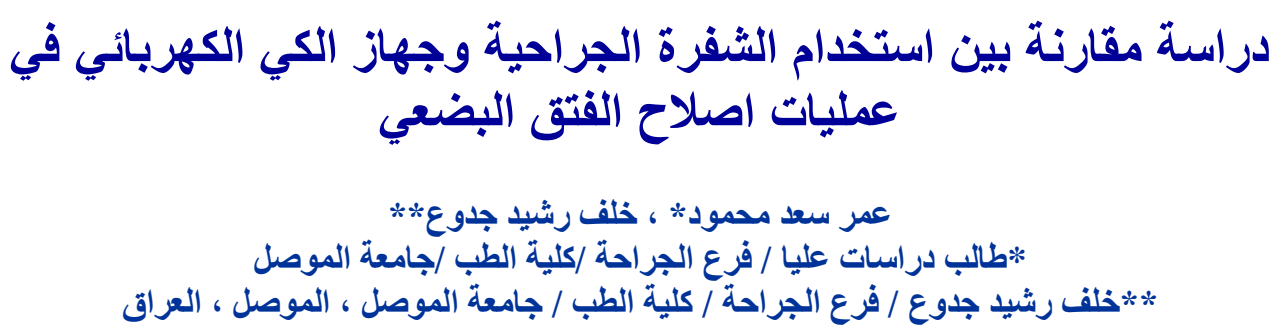

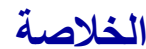

الخلفية: الفتق البضعى مشكلة شائعة فى ممارستنا الجراحية وهو يمثل تحديًا نظرًا لارتفاع معدل المضاعفات مثل الورم المصلى

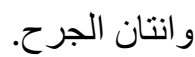
الهدف من هذه الدراسة: هو تقييم مساهمة جهاز الكىى الحرارى فى تكوين الورم المصلى و انتان وتفزر الجرح فى عملية اصلاح الفتق

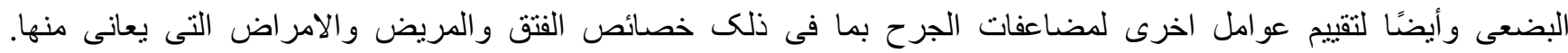

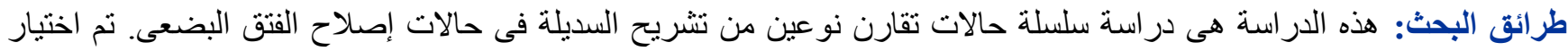

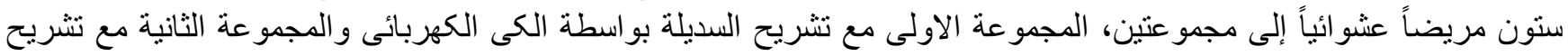




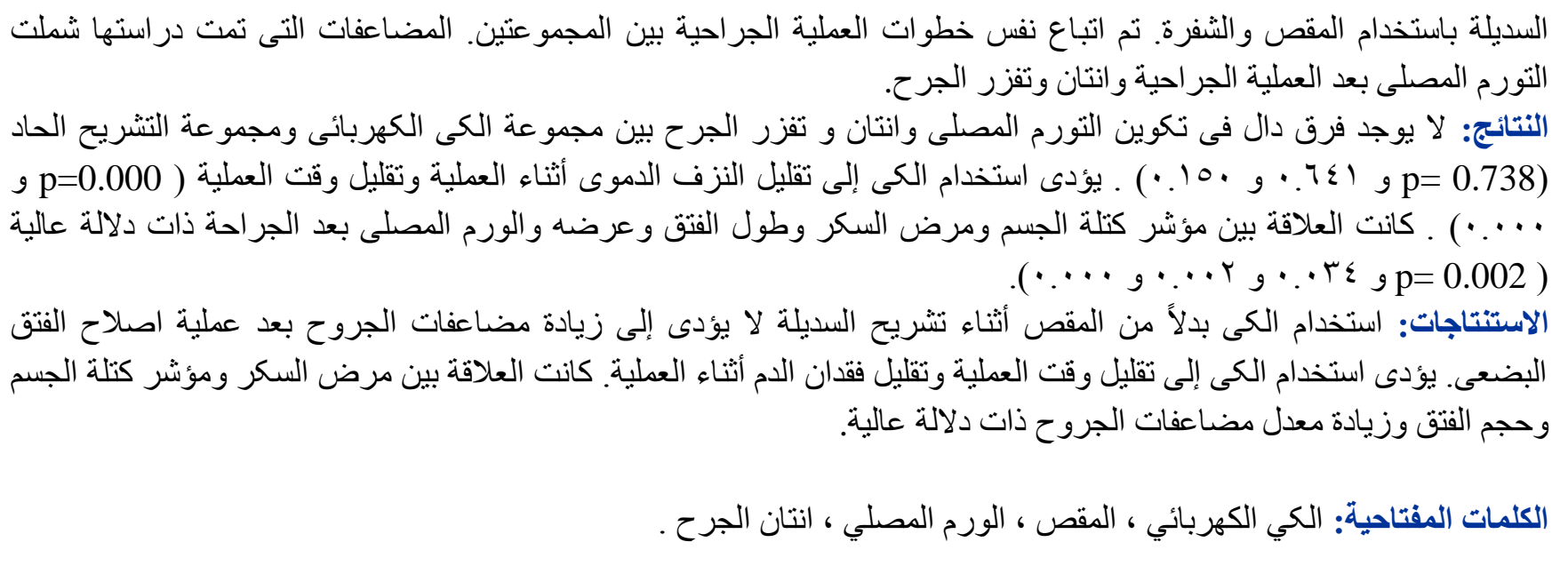

\section{INTRODUCTION}

ncisional hernia is a visceral protrusion from the peritoneal cavity through a path formed after injury caused by cutting (operative incisions, laparoscopic trocar incisions, stab wounds, etc.) ${ }^{1}$. It is a concealed type of wound dehiscence. Incisional hernia is one of the most common surgical conditions and its incidence after laparotomies is thought to be $10-20 \%^{2,3}$. Incisional hernia repair continues to be challenging despite the significant advance in surgical technique, with recurrence rates ranging from $5 \%$ to $50 \%$ depending on the type of repair used ${ }^{4}$. Surgical management of incisional hernia includes either simple closure in patients with small hernias, or a more complex operation in patients with larger hernias that involve loss of abdominal wall domain; in which simple closure will not be sufficient and may lead to closure under tension and abdominal compartment syndrome ${ }^{5}$. The high recurrence rates with primary suture repair have led to an increased use of prosthetic mesh to provide for a tension free repair ${ }^{4}$. Several techniques of securing the mesh to the fascia have been used, with the most common being mesh onlay, mesh inlay, retrorectus placement, and intraperitoneal underlay. The onlay technique which was used in our study, requires wide tissue undermining and flap dissection to clear a healthy fascia around the hernial defect. The flap dissection performed either by using knife and scissors or by using electrocautery. Since Dr. Harvey Cushing achieved the first operation using electrosurgical instrument in 1926, electrocautery has become a crucial component in the operating theatre regardless of the surgical procedure performed ${ }^{6}$.
Although cutting electrocautery can be superior to sharp dissection in decreasing intraoperative bleeding and dissection time, numerous reports blamed electrocautery with increased incidence of wound infection and impaired healing ${ }^{7,8}$. The aim of this study is to compare cutting electrocautery versus scalpel for flap dissection in open incisional hernial surgery.

\section{PATIENTS AND METHODS}

Sixty patients between January and November 2019 in Al-Jumhori and Al-Zahrawi hospitals included in this study underwent elective open midline incisional hernia mesh repair and were allocated alternatively to either scalpel $(n=30)$, or diathermy $(n=30)$ groups.

All patients included in our study were aged more than 18 years, had symptomatic incisional hernia evident by clinical examination, mainly periumbilical and lower midline abdominal and were in (ASA) class equal or less than III. Patients who required emergency operation (intestinal obstruction, strangulation and peritonitis), those with (ASA) more than III, patients on anticoagulants or antiplatelet and patients with recurrent incisional hernias were excluded.

Among the population sample, 43 were females and 17 were males, their age range between 22 and 78 years, their BMI range between 24 and 42.5, their defect length range between $4-13 \mathrm{~cm}$ and their defect width range from 1-7 $\mathrm{cm}$, duration more than one year was found in 31 patients and preoperative reducibility was evident in 23 patients.

On the day of surgery patients were randomized with odd numbers being entered into cautery group and even numbers into scissors group, informed 
consent was taken from all patients. On the electrocautery group, subcutaneous and flap dissection were done by using cautery with energy setting on 30 in cutting mode, while on the other group dissection was made with knife and scissors with diathermy forceps on coagulation mode only for hemostasis. The sac was dissected by blunt rather than sharp dissection in both groups, also the use of cautery was avoided in areas of dense adhesion between abdominal wall and viscera to avoid inadvertent injury to the bowel.

All patients received prophylactic antibiotic and analgesia. The surgical technique was the same which include flap formation to clear the fascia around the defect, herniotomy, closure of the defect by non-absorbable suture then onlay application of polypropylene mesh. Assessment of intraoperative blood loss was done by measuring the weight of surgical sponges. Close suction drains were used for all cases. The operative course was smooth without intraoperative complications for all cases. All cases discharged from hospital the same day or on the next postoperative day. Patients were instructed to wear compression brace. All patients were followed up at one week and at one-month post operatively and had their drains removed when their output was less than $25 \mathrm{ml} /$ day. Patients who developed postoperative complications were examined earlier than 1 month when required and were followed up until their complications resolved. The aim of the follow up was to detect cases of seroma and wound complications including SSI and dehiscence.

In this study, ultrasound was not ordered routinely to look for asymptomatic postoperative seroma, but it was ordered when symptomatic patient suspected to have seroma especially in the obese. When seroma diagnosed; aspiration by wide bore needle in the clinic was done, sometimes repeated aspirations and even reinsertion of drain into the seroma cavity were required.

The comparison data included personal characteristics and comorbidities (BMI, DM, HT), hernial characteristics (length and width of the defect, duration, reducibility), and technique characteristics (technique of flap dissection, operative time, intra operative blood loss).

\section{DATA ANALYSIS AND STATISTICAL TESTS}

Data tabulation and categorization were made by Microsoft Excel-2016. Description and analysis statistics were performed using Minitab version 18.1 software statistical program. The description statistics included frequencies and percentages for categorical variables whereas mean \pm Standard Deviation (SD) were performed for measurable variables. T-test for two Independent means was used for the comparison between quantitative parameters. Also chi-square test was used for differences between categorical variables. P-value $\leq 0.05$ was considered statistically significant throughout data analysis.

\section{RESULTS}

\section{Personal Characteristics :}

Sixty patients included into this study were randomized according to flap formation in to two groups, sharp dissection group $(n=30)$ and electro cautery dissection group $(n=30)$. There were no significant differences in personal, hernial characteristics and past medical problems between the two groups (table 1,2) figure 1.

\section{Complications:}

In total eleven patients developed postoperative seroma, five developed postoperative SSI and two developed skin sloughing with wound dehiscence. In the sharp dissection group, six patients developed seroma, two of them complicated by SSI. In the electro cautery dissection group five patients developed seroma, two of them complicated by SSI and dehiscence and one patient developed SSI without preceding seroma. The difference was not significant in seroma formation, SSI rates and wound dehiscence rate between the two groups. There was a significant reduction in the operative time and intraoperative blood loss between the two groups (table 3). The incidence of wound infection in both groups was higher when accompanied by seroma ( $80 \%$ vs $20 \% \mathrm{p}=0.0002)$.

The relation between $\mathrm{BMI}$ and frequency of postoperative complications was significant (table 4).

There was a significant relation between preoperative reducibility and development of seroma which was more common in irreducible hernias (table 5). The relation between the defect length, width and frequency of postoperative complications was highly significant (table 6,7).

There was a significant relation between DM and frequency of postoperative complications (table8) but the relation between $\mathrm{HT}$ and postoperative complications was not significant (table 9) figure 2. 


\section{DISCUSSION}

Incisional hernia surgery is a challenging procedure because it is not free of complications like seroma formation, SSI and recurrence?. Seroma is especially liable to happen when large skin flaps are created during the operation. Small seromas usually resolve spontaneously in a few weeks without complications but larger symptomatic persistent seromas are hard to manage and multiple aspirations may be needed which will increase the risk of SSI and hernia recurrence ${ }^{10}$. Seroma is usually present postoperatively in most cases and can be detected by ultrasound but it is subclinical and asymptomatic and considered incident rather than complication ${ }^{11}$.

The pathogenesis of seroma is believed to be due to excessive soft tissue dissection with disruption of vascular and lymphatic channels which result in accumulation of fluid in the dead space between the subcutaneous flap and the fascia, other factors include inflammatory mediators released after surgery, increased permeability of the capillaries and the resulting shearing force between the fascia and the flaps ${ }^{12,13}$. In addition, presence of foreign body like mesh considered a significant risk for seroma formation in herniorrhaphy cases ${ }^{14}$.

SSI and infection of the mesh can be grave complications, often requiring removal of the mesh. SSI in open mesh repairs is thought to be $3 \%-10 \%$ and it is the most common reason that a mesh is explanted and leads to higher recurrence rates ${ }^{15}$.

\section{Cautery Vs Sharp Dissection:}

Dissection methods vary greatly between surgeons; some prefer sharp dissection because they believe that cutting electrocautery associate with higher seroma rate ${ }^{7}$. Results from this study indicate that use of an electrocautery dissection instead of sharp dissection does not result in a significant increase in seroma, SSI and dehiscence, also it results in a significant reduction in the operative time and intraoperative blood loss.

This may be explained by the fact that local tissue heating increases subcutaneous oxygen tension, thus enhancing the resistance of the surgical wounds to infection ${ }^{16}$. In addition, the use of cautery results in better hemostasis and sealing of lymphatics during dissection which explain reduced or comparable seroma rates between the two groups ${ }^{6}$.

\section{Hernia Length And Width:}

In our study there was a highly significant relation between the frequency of wound complications and the defect length and width (table 6,7). The explanation for this relation is the need for more flap dissection in larger defects in order to clear healthy fascia around the hernial neck. Kaafarani et al. ${ }^{17}$ in his study of seroma predictors in incisional hernia also found increase incidence of seroma in larger size defects but not statistically significant $p=0.519$ ).

\section{Effect Of Comorbidities:}

Results of this study show a very significant relation between the incidence of wound complications and diabetes mellitus (table 8). On the other hand, the relation with hypertension was not significant (table 9). Kaafarani et al. ${ }^{17}$ also found increase incidence of seroma among diabetic patients but not statistically significant $(p=0.259)$. Licari et al. ${ }^{18}$ in his study of seroma risk factors in abdominal wall surgery found significant relation between hyperglycemia and seroma $(p=0.004)$.

Diabetes mellitus is a known cause of poor wound healing. Uncontrolled DM leads to impaired leukocyte function, reduced angiogenesis, and collagen synthesis ${ }^{19}$. Also, micro and macroangiopathy which occur in diabetes contributes to poor tissue perfusion and local hypoxemia which lead to increased incidence of wound infection and dehiscence ${ }^{20}$.

\section{Effect Of The BMI:}

In this study there was a significant relation between high BMI and frequency of wound complications (table 4). Kim et al. ${ }^{21}$ in his study of risk factors for seroma in abdominoplasty cases found significant relation between high BMI and seroma $(p<0.05)$. Ghnnam et al. $^{22}$ in his study of the BMI effect on the abdominoplasty operations, found increase incidence of seroma in high BMI patients but not statistically significant $(p=0.4)$. The explanation for the high seroma rate in obese patient may be due to thick abdominal pannus encountered in the majority of these patients, which require more dissection and undermining which lead to more shearing force. Obesity increases the risk of SSI by many factors ${ }^{23}$. The adipose tissue is active metabolically and immunologically and, through generation of proinflammatory adipokines and cytokines, leads to the development of the metabolic syndrome ${ }^{24}$. Many of these agents have effects on cells participating in the healing process. Obese patients have been found to have reduced oxygenation in the subcutaneous tissue, thus 
leading to wound hypoxia which lead to poor wound healing 25 .

\section{CONCLUSIONS}

The use of electro cautery instead of knife and scissors for flap dissection does not result in increased incidence of seroma, SSI and dehiscence in incisional hernia patients, also it results in a significant reduction in the operative time and intraoperative blood loss. Other factors include hernial length, width, DM and BMI are important predictors for seroma formation and SSI.

\section{Acknowledgment:}

My great thanks and deep appreciation to my Senior General Surgeons at Al-Jumhory Teaching Hospital for their help, support and continuous guidance.

Great thanks to my colleagues and all medical staff for their support....

\section{Conflict of Interest:}

The authors declare that there are no conflicts of interest regarding the publication of this manuscript.

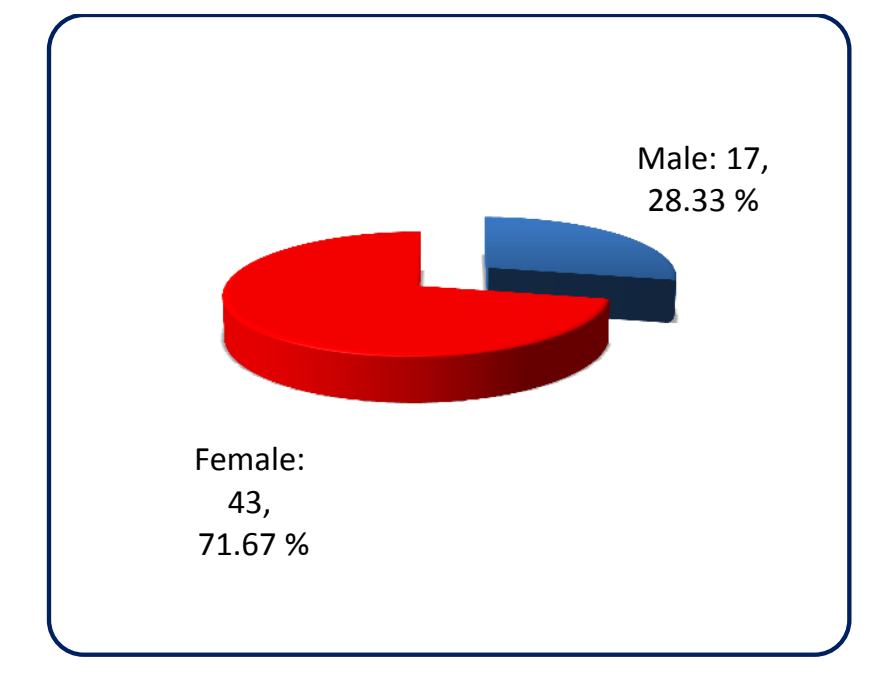

Figure (1): Gender distribution of incisional hernia patients, $(n=60)$.

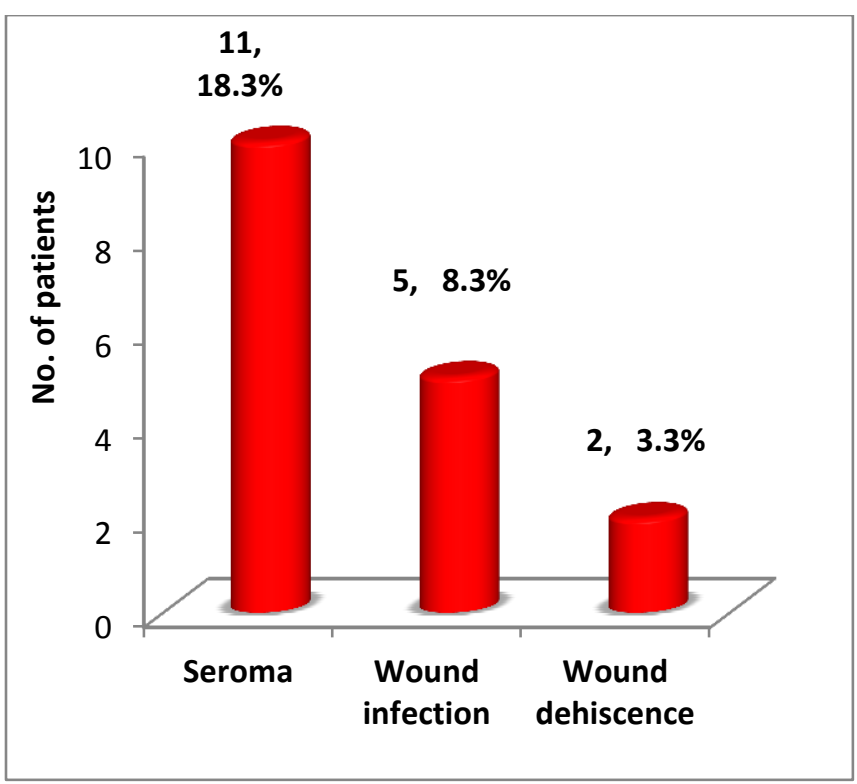

Figure (2): Percentages of complications following of incisional hernia repair, $(n=60)$. 
Table (1): Personal characteristics of the study sampled population, $(n=60)$.

\begin{tabular}{|l|c|c|c|}
\hline Characteristics & Mean & SD & Range \\
\hline Age (years) & 48.0 & 13.24 & $22.0-78.0$ \\
\hline BMI (kg/m ${ }^{2}$ ) & 30.59 & 3.576 & $\begin{array}{c}24.00- \\
42.50\end{array}$ \\
\cline { 1 - 3 } $\begin{array}{l}\text { Defect length } \\
\text { (cm) }\end{array}$ & 7.94 & 2.1 & $4-13 \mathrm{~cm}$ \\
\hline Defect width (cm) & 3.77 & 1.49 & $1-7 \mathrm{~cm}$ \\
\hline & No. & $\%$ & \multicolumn{1}{|c|}{--} \\
\hline $\begin{array}{l}\text { Cigarette } \\
\text { smokers }\end{array}$ & 11 & 18.33 & --- \\
\hline DM & 13 & 21.66 & --- \\
\hline HT & 9 & 15 & \\
\hline
\end{tabular}

Table (2): Comparison in personal, hernial characteristics and comorbidities between the two groups

\begin{tabular}{|c|c|c|c|}
\hline \multirow[b]{2}{*}{ Parameters } & \multicolumn{2}{|c|}{$\begin{array}{c}\text { Incisional hernia } \\
\text { surgery }\end{array}$} & \multirow[b]{2}{*}{ P-value* } \\
\hline & $\begin{array}{c}\text { Electrocautery } \\
{[n=30]} \\
\text { Mean } \pm \text { SD }\end{array}$ & $\begin{array}{c}\text { Scissor } \\
{[n=30]} \\
\text { Mean } \pm \\
\text { SD }\end{array}$ & \\
\hline Age (years) & $49.67 \pm 14.05$ & $\begin{array}{c}46.37 \pm \\
12.38\end{array}$ & 0.169 \\
\hline BMI $\left(\mathrm{kg} / \mathrm{m}^{2}\right)$ & $30.65 \pm 3.96$ & $\begin{array}{c}30.52 \pm \\
3.21\end{array}$ & 0.443 \\
\hline \begin{tabular}{|l} 
Defect \\
length $(\mathrm{cm})$
\end{tabular} & $8.11 \pm 2.07$ & $\begin{array}{l}7.77 \pm \\
2.17\end{array}$ & 0.268 \\
\hline $\begin{array}{l}\text { Defect width } \\
\text { (cm) }\end{array}$ & $3.95 \pm 1.38$ & $3.6 \pm 1.6$ & 0.184 \\
\hline--- & No. (\%) & No. (\%) & --- \\
\hline Gender:Male & $10(58.82)$ & $\begin{array}{c}7 \\
(41.18) \\
\end{array}$ & \multirow{2}{*}{0.390} \\
\hline Female & $20(46.51)$ & $\begin{array}{c}23 \\
(53.49)\end{array}$ & \\
\hline DM & $6(20)$ & 7 (23.3) & 0.754 \\
\hline HT & $5(16.7)$ & \begin{tabular}{|l|}
$4(13.3)$ \\
\end{tabular} & 0.718 \\
\hline
\end{tabular}

* T-test for two Independent means was used for quantitative variables and Chi-square test for categorical variables, $\mathbf{d} . \mathbf{f}=\mathbf{1}$.
Table (3): Comparison in wound complications, operative time and intraoperative blood loss between the two groups.

\begin{tabular}{|c|c|c|c|}
\hline \multirow[b]{2}{*}{ Parameters } & \multicolumn{2}{|c|}{$\begin{array}{l}\text { Incisional hernia } \\
\text { surgery }\end{array}$} & \multirow{2}{*}{$\begin{array}{c}\text { P- } \\
\text { value* }\end{array}$} \\
\hline & \begin{tabular}{|c}
$\begin{array}{c}\text { Electrocautery } \\
{[n=30]} \\
\text { No. }(\%)\end{array}$ \\
\end{tabular} & $\begin{array}{l}\text { Scissor } \\
{[n=30]} \\
\text { No. }(\%) \\
\end{array}$ & \\
\hline Seroma & 5 (16.7) & $6(20)$ & 0.738 \\
\hline SSI & $3(10.0)$ & $2(6.7)$ & 0.641 \\
\hline $\begin{array}{l}\text { Wound } \\
\text { dehiscence }\end{array}$ & $2(6.7)$ & $0(0.0)$ & 0.150 \\
\hline --- & Mean \pm SD & $\begin{array}{l}\text { Mean } \pm \\
\text { SD }\end{array}$ & --- \\
\hline $\begin{array}{l}\text { Operative } \\
\text { time (min) }\end{array}$ & $63.53 \pm 13.62$ & $\begin{array}{l}91.16 \pm \\
12.43\end{array}$ & 0.000 \\
\hline $\begin{array}{l}\text { Intraoperative } \\
\text { blood loss } \\
(\mathrm{ml})\end{array}$ & $120 \pm 25.76$ & $\begin{array}{r}180.83 \\
\pm 59.33\end{array}$ & 0.000 \\
\hline
\end{tabular}

* T-test for two Independent means was used for quantitative variables and Chi-square test for categorical variables, d.f $=1$.

Table (4): The relationship between BMI and frequency of wound complications.

\begin{tabular}{|c|c|c|c|}
\hline \multirow[b]{2}{*}{$\begin{array}{l}\text { Postoperative } \\
\text { complications }\end{array}$} & \multicolumn{2}{|c|}{$\begin{array}{l}\text { Postoperative } \\
\text { complications }\end{array}$} & \multirow[b]{2}{*}{$\begin{array}{c}\text { P- } \\
\text { value* }\end{array}$} \\
\hline & $\begin{array}{c}\text { Present } \\
\text { Mean BMI } \pm \\
\text { SD }\left(\mathrm{kg} / \mathrm{m}^{2}\right)\end{array}$ & $\begin{array}{c}\text { Absent } \\
\text { Mean BMI } \pm \\
\text { SD }\left(\mathrm{kg} / \mathrm{m}^{2}\right)\end{array}$ & \\
\hline Seroma & $33.3 \pm 2.85$ & $29.98 \pm 3.45$ & 0.002 \\
\hline SSI & $35.2 \pm 1.64$ & $30.17 \pm 3.40$ & 0.001 \\
\hline $\begin{array}{l}\text { Wound } \\
\text { dehiscence }\end{array}$ & $36.0 \pm 2$ & $30.4 \pm 3.46$ & 0.0 \\
\hline
\end{tabular}


Table (5): The relationship between hernia duration, reducibility and frequency of wound complications.

\begin{tabular}{|c|c|c|c|c|c|c|}
\hline \multirow{3}{*}{$\begin{array}{c}\text { Hernia } \\
\text { character } \\
\text { istics }\end{array}$} & \multicolumn{6}{|c|}{ complications } \\
\hline & \multicolumn{3}{|c|}{ Seroma } & \multicolumn{3}{|c|}{ SSI } \\
\hline & $\begin{array}{c}\text { pres } \\
\text { ent }\end{array}$ & $\begin{array}{l}\text { abs } \\
\text { ent }\end{array}$ & $\begin{array}{c}P \\
\text { val } \\
\text { ue }\end{array}$ & $\begin{array}{c}\text { pres } \\
\text { ent }\end{array}$ & $\begin{array}{l}\text { abs } \\
\text { ent }\end{array}$ & $\begin{array}{c}P \\
\text { val } \\
\text { ue }\end{array}$ \\
\hline $\begin{array}{l}\text { Duration } \\
>1 \text { year }\end{array}$ & $\begin{array}{l}45.4 \\
\%\end{array}$ & $\begin{array}{l}53.0 \\
6 \%\end{array}$ & $\begin{array}{l}0.6 \\
48\end{array}$ & $60 \%$ & $\begin{array}{l}50.9 \\
\%\end{array}$ & $\begin{array}{l}0.6 \\
96\end{array}$ \\
\hline $\begin{array}{l}\text { Preopera } \\
\text { tive } \\
\text { reducibili } \\
\text { ty }\end{array}$ & $\begin{array}{l}9.09 \\
\%\end{array}$ & $\begin{array}{l}44.8 \\
9 \%\end{array}$ & $\begin{array}{l}0.0 \\
27\end{array}$ & $20 \%$ & $\begin{array}{l}40 \\
\%\end{array}$ & $\begin{array}{l}0.3 \\
78\end{array}$ \\
\hline
\end{tabular}

${ }^{*}$ Chi-square test was used, $d . f=1$.

Table (6): The relationship between hernial defect length and frequency of wound complications.

\begin{tabular}{|c|c|c|c|}
\hline \multirow[b]{2}{*}{$\begin{array}{l}\text { Postoperative } \\
\text { complications }\end{array}$} & \multicolumn{2}{|c|}{$\begin{array}{l}\text { Postoperative } \\
\text { complications }\end{array}$} & \multirow[b]{2}{*}{$\begin{array}{c}\text { P- } \\
\text { value* }\end{array}$} \\
\hline & $\begin{array}{c}\text { Present } \\
\text { Mean length } \\
\pm \mathrm{SD}(\mathrm{cm}) \\
\end{array}$ & \begin{tabular}{|c|} 
Absent \\
Mean length \\
$\pm \mathrm{SD}(\mathrm{cm})$ \\
\end{tabular} & \\
\hline Seroma & $9.5 \pm 2.19$ & $7.59 \pm 1.94$ & 0.002 \\
\hline SSI & $9.82 \pm 1.18$ & $7.77 \pm 2.09$ & 0.018 \\
\hline $\begin{array}{l}\text { Wound } \\
\text { dehiscence }\end{array}$ & $10.8 \pm 1.13$ & $7.84 \pm 2.07$ & 0.025 \\
\hline
\end{tabular}

* T-test for two Independent means was used.

Table (7): The relationship between hernial defect width and frequency of wound complications.

\begin{tabular}{|c|c|c|c|}
\hline \multirow[b]{2}{*}{$\begin{array}{l}\text { Postoperative } \\
\text { complications }\end{array}$} & \multicolumn{2}{|c|}{$\begin{array}{l}\text { Postoperative } \\
\text { complications }\end{array}$} & \multirow[b]{2}{*}{$\begin{array}{c}\text { P- } \\
\text { value }\end{array}$} \\
\hline & $\begin{array}{c}\text { Present } \\
\text { Mean width } \\
\pm \text { SD }(\mathbf{c m})\end{array}$ & $\begin{array}{c}\text { Absent } \\
\text { Mean width } \\
\pm \text { SD }(\mathrm{cm})\end{array}$ & \\
\hline Seroma & $5.81 \pm 1.12$ & $3.31 \pm 1.14$ & 0.000 \\
\hline SSI & $6.3 \pm 0.75$ & $3.54 \pm 1.32$ & 0.000 \\
\hline $\begin{array}{l}\text { Wound } \\
\text { dehiscence }\end{array}$ & $6.75 \pm 0.35$ & $3.67 \pm 1.41$ & 0.000 \\
\hline
\end{tabular}

* T-test for two Independent means was used.
Table (8): The relationship between DM and frequency of wound complications.

\begin{tabular}{|c|c|c|c|}
\hline \multirow{2}{*}{$\begin{array}{l}\text { Postoperative } \\
\text { complications }\end{array}$} & \multicolumn{2}{|c|}{$\begin{array}{c}\text { Postoperative } \\
\text { complications } \\
\text { In diabetic patients }(n=13)\end{array}$} & \multirow{2}{*}{$\begin{array}{c}\text { P. } \\
\text { value* }\end{array}$} \\
\hline & $\begin{array}{l}\text { Present } \\
\text { No. (\%) }\end{array}$ & $\begin{array}{l}\text { Absent } \\
\text { No. (\%) }\end{array}$ & \\
\hline $\begin{array}{l}\text { Seroma } \\
(n=11)\end{array}$ & $5(38.4)$ & $8(61.5)$ & 0.034 \\
\hline SSI $(n=5)$ & $3(23.07)$ & $10(76.92)$ & 0.029 \\
\hline $\begin{array}{l}\text { Wound } \\
\text { dehiscence } \\
(\mathrm{n}=2)\end{array}$ & 1 (7.69) & $12(92.3)$ & 0.322 \\
\hline
\end{tabular}

${ }^{*}$ Chi-square test was used, $d . f=1$.

Table (9): The relationship between HT and frequency of wound complications.

\begin{tabular}{|l|c|c|c|}
\hline \multirow{2}{*}{$\begin{array}{l}\text { Postoperative } \\
\text { complications }\end{array}$} & \multicolumn{2}{|c|}{$\begin{array}{c}\text { Postoperative } \\
\text { complications } \\
\text { In hypertensive patients } \\
(n=9)\end{array}$} & $\begin{array}{c}\text { P. } \\
\text { value* }\end{array}$ \\
\cline { 2 - 4 } & $\begin{array}{l}\text { Present } \\
\text { No. (\%) }\end{array}$ & $\begin{array}{c}\text { Absent } \\
\text { No. (\%) }\end{array}$ & \\
\hline $\begin{array}{l}\text { Seroma } \\
(n=11)\end{array}$ & $3(33.3)$ & $6(66.7)$ & 0.207 \\
\hline SSI $(n=5)$ & $1(11.1)$ & $8(88.9)$ & 0.743 \\
\hline $\begin{array}{l}\text { Wound } \\
\text { dehiscence } \\
(n=2)\end{array}$ & $1(11.1)$ & $8(88.9)$ & 0.158 \\
\hline
\end{tabular}

${ }^{\star}$ Chi-square test was used, d.f $=1$.

\section{REFERENCES}

1.Rives J, Pire JC, Flament JB, Palot JP, Chevrel $J P$. Hernias and surgery of the abdominal wall. 2nd ed. Berlin, Heidelberg, New York: Springer Verlag; 1998. p. 31

2. Fink C, Baumann $P$, Wente M.N, Knebel $P$, Bruckner T, Ulrich A, et al. Incisional hernia rate 3 years after midline laparotomy. Br J Surg. 2014; 101: 51-54.

3.Bosanquet D.C, Ansell J, Abdelrahman T, Cornish J, Harries R, Stimpson A, et al. Systematic review and meta-regression of factors affecting midline incisional hernia rates: analysis of 14,618 patients. PLoS One. 2015; 10: e0138745. 
4.Burger JW, Luijendijk RW, Hop WC, Halm JA, Verdaasdonk EG, Jeekel J. Long- term follow up of a randomized controlled trial of suture versus mesh repair of incisonal hernia. Ann Surg. 2004;240(4): 578-83.

5. Mavrodin Cl, Pariza G, Ion D, Antoniac VI. Abdominal compartment syndrome -- a major complication of large incisional hernia surgery. Chirurgia (Bucur). 2013;108(3): 414-7.

6. Glover JL, Bendick PJ, Link WJ. The use of thermal knives in surgery: electrosurgery, lasers, plasma scalpel. Curr Probl Surg. 1978 ;15:1.

7.Rousseau P, Vincent H, Potier B, Arnaud D, Darsonval V. Diathermocoagulation in cutting mode and large flap dissection. Plast Reconstr Surg. $2011 ; 127(5): 2093 \mathrm{e} 8$.

8. Ozgiin $\mathrm{H}$, Tuncyurek $\mathrm{P}$, Boylu $\mathrm{S}$, Erpek $\mathrm{H}$, Yenisey $\mathrm{C}$, Kose $\mathrm{H}$, et al. The right method for midline laparotomy: what is the best choice for wound healing? Acta Chir. Belg. 2007;107:682686.

9. Poelman MM, Langenhorst BL, Schellekens JF, Schreurs WH. Modified onlay technique for the repair of the more complicated incisional hernias: single-centre evaluation of a large cohort. Hernia. $2010 ; 14(4): 369-74$.

10. Korenkov M, Paul A, Sauerland S, Neugebauer E, Arndt M, Chevrel JP, et al. Classification and surgical treatment of incisional hernia. Results of an experts' meeting. Langenbecks Arch Surg. 2001;386(1):65-73.

11. Susmallian S, Gewurtz G, Ezri T, Charuzi I. Seroma after laparoscopic repair of hernia with PTFE patch: is it really a complication? Hernia. 2001;5(3):139-41.

12. Bendavid R, Abrahamson J, Arregui ME, Flament JB, Phillips EH. Abdominal wall hernias. Principles and management. New York: Springer; 2001. pp. 753-6.

13. Salamone G, Licari L, Agrusa A, Romano G, Cocorullo G, Gulotta G. Deep seroma after incisional hernia repair. Case reports and review of the literature. Ann Ital Chir. 2015 May;12:86(ePub):S2239253X15022938.

14. Albino FP, Patel KM, Nahabedian MY, Sosin S, Attinger CE, Bhanot $P$. Does mesh location matter in abdominal wall reconstruction? A systematic review of the literature and a summary of recommendations. Plast Reconstr Surg. 2013;132(5):1295-304.

15. hawn MT, Gray SH, Snyder CW, Graham LA, Finan KR, Vick CC. Predictors of mesh explantation after incisional hernia repair. Am J Surg. $2011 ; 202(1): 28-33$.
16. Ikeda T, Tayefeh F, Sessler DI, Kurz A, Plattner $\mathrm{O}$, Petschnigg $\mathrm{B}$, et al. Local radiant heating increases subcuteneous oxygen tension. Am J Surg. $1998 ; 175: 33-7$.

17. Kaafarani HM, Hur K, Hirter A, Kim LT, Thomas A, Berger $\mathrm{DH}$, et al. Seroma in ventral incisional herniorrhaphy: incidence, predictors and outcome. Am J Surg. 2009 Nov;198(5):639-644.

18. Licari L, Salamone G, Parinisi Z, Campanella S, Sabatino C, Ciolino G, et al. Multiparametric evaluation of risk factors associated to seroma formation in abdominal wall surgery. G Chir. $2017 ; 38: 280-284$.

19. Delamaire M, Maugendre D, Moreno M, Le Goff MC, Allannic H, Genetet B. Impaired leucocyte functions in diabetic patients. Diabet Med. 1997 ; 14:29-34.

20. Joshi N, Caputo GM, Weitekamp MR, Karchmer AW. Infections in patients with diabetes mellitus. N Engl J Med. 1999 ;341:1906-12.

21. Kim J, Stevenson TR. Abdominoplasty, Liposuction of the Flanks, and Obesity: Analyzing Risk Factors for Seroma Formation. Plast Reconstr Surg. 2006 ;117:773-779.

22. Ghnnam W, Elrahawy A, Moghazy M. The Effect of Body Mass Index on Outcome of Abdominoplasty Operations. World J Plast Surg. 2016;5(3):244-251.

23. Thelwall S, Harrington $P$, Sheridan E, Lamagni T. Impact of obesity on the risk of wound infection following surgery: results from a nationwide prospective multicentre cohort study in England. Elsevier. $2015 ; 21: 1008 . e 1-1008 . e 8$.

24. Ouchi N, Parker JL, Lugus JJ, Walsh K. Adipokines in inflammation and metabolic disease. Nat Rev Immunol. $2011 ; 11(2): 85-97$.

25. Kabon B, Nagele A, Reddy D, Eagon C, Fleshman J.W, Sessler D, et al. Obesity decreases perioperative tissue oxygenation. Anesthesiology. 2004;100:274-280 . 